\title{
ТАРАС ШЕВЧЕНКО І СПРОБА НАЦІОНАЛЬНОГО ВІДРОДЖЕННЯ УКРАЇНИ НА ПОЧАТКУ 1960-Х РР.
}

\section{Чорна Л. О.}

\section{ВСТУП}

Духовна спадщина Тараса Шевченка вже понад півтора століття впливає на розвиток суспільної думки в Україні, є життєдайним джерелом української національної ідеї. Шевченкове слово, незважаючи на плин років, продовжує торкатися душі кожного свідомого українця, примушує замислитися: «...що ми?.. Чиї сини? яких батьків?» 1 .

Тарасова (колишня Чернеча) гора 3 часу поховання Тараса Шевченка стала місцем паломництва українських патріотів, адже, за висловом Івана Франка, поет став «володарем в царстві духа» ${ }^{2}$ для всіх тих, кому не байдужа була доля України.

У сучасному суспільстві ще й досі $\epsilon$ невирішеними проблеми, які турбували Тараса Шевченка. Це, зокрема, статус української мови в Україні: продовжують точитися суперечки стосовно окремих положень мовного закону, сфер застосування української мови в українській державі. Зрештою, прагнення частини суспільства до «руского міра» привели в Україну агресора. У боротьбі українства за свою мову і культуру яскравою сторінкою $є$ початок 1960-х років, період так званої «хрущовської відлиги», який співпав із відзначенням Шевченківських ювілеїв 1961-1964 років. Тоді на захист рідної мови піднялося як старше покоління української інтелігенції, так і молодь, яка ввійшла в історію України під назвою шістдесятники. За короткий час виникли і розвивалися нові напрями в літературі і мистецтві. Шістдесятники зверталися до витоків української культури - народних традицій, звичаїв, української народної пісні. Активізувалася і порівняно нова народна традиція, яка склалася із похованням Тараса

1 Шевченко Т.Г. І мертвим, і живим і ненарожденним в Україні і не в Україні моє дружнєє посланіє / Тарас Шевченко. Зібрання творів : У 6 т. Київ, 2003. Т. 1: Поезія 1837-1847. С. 348-354.

${ }^{2}$ I. Франко. Присвята / Твори в 50-ти томах. Київ : Наукова думка, 1983. T. 39. C. 255 . 
Шевченка на Чернечій горі, - здійснювати щорічні подорожі до його могили.

Мета дослідження - на основі писемних джерел періоду 19611964 років, що зберігаються у фондах та науковому архіві Шевченківського національного заповідника, документів Центрального державного архіву громадських об'єднань України, мемуарних публікацій шістдесятників - висвітлити значення феномену Тараса Шевченка для української громадськості на початку 1960-х років у їі спротиву русифікації України.

\section{1. Джерельна база дослідження}

Джерельною базою дослідження $\epsilon$ насамперед документальні матеріали, які знаходяться у Центральному державному архіві громадських об'єднань України (далі - ЦДАГО України): фонд 1 Центральний комітет компартії України. Зокрема, тут акумульовані документи, що розкривають як підготовку до офіційного відзначення ювілеїв Тараса Шевченка та їх проведення, так і боротьбу влади із «самовільним» відзначенням Шевченківських днів та інших дат, які стосувалися української культури. Архівні справи свідчать, як поступово із суто культурницьких заходів молода українська інтелігенція переходить до політичного спротиву. Подібну інформацію містить і фонд 7 (ЦК ЛКСМУ).

Активну участь у підготовці офіційних заходів із вшанування Тараса Шевченка брав Петро Тимофійович Тронько, який у 19601961 роках завідував відділом пропаганди і агітації ЦК КПУ, а з 10 березня 1961 р. - заступник голови Ради Міністрів Української РСР займався питаннями культури, освіти, охорони здоров'я. Був заступником голови Всесоюзного оргкомітету із підготовки до сторіччя 3 дня смерті (1961) та 150-річчя (1964) від дня народження Т.Г. Шевченка. Дублетні матеріали про підготовку до відзначення ювілеїв (стенограми засідань Всесоюзного та Республіканського ювілейних комітетів, інформація про видання творів Тараса Шевченка в СРСР і за рубежем, впорядкування Шевченківських місць, відкриття пам'ятників і пам'ятних знаків тощо) були передані Петром Троньком у 1990-ті рр. до наукового архіву Шевченківського національного заповідника (далі - НА ШНЗ). У НА ШНЗ зберігаються книги обліку відвідувачів Тарасової Гори кінця 1950-х - початку 1960-х рр., які свідчать про тисячі прибулих до могили Тараса Шевченка (на той час вхід до музею був безкоштовний, і таким чином вівся облік відвідувачів; прізвищ не писали, але зазначали соціальний стан прибулих). Із 1964 р. також ведеться «Літопис», куди черговий 
науковий співробітник записує події, що відбуваються на Тарасовій Горі. Окремо навіть вклеєно аркуш з інформацією про відзначення 100-річчя смерті Тараса Шевченка у 1961 р.

У НА ШНЗ зберігається понад два десятки листів, написаних Тарасом Івановичем Франком (сином Івана Франка) на адресу Державного музею-заповідника «Могила Т.Г. Шевченка», а також копії звернень до різних організацій і установ стосовно необхідності міжнародного відзначення Шевченківських ювілейних дат. Під листами стояла домашня адреса Тараса Франка, на яку пропонувалося давати відповідь. Багато листів на цю ж тематику - із підписами філолога Юрія Назаренка, Остапа Лисенка, художника Василя Касіяна.

Цікавим джерелом дослідження $\epsilon$ «Книги вражень», ведення яких розпочато ще 1894 р. у першому народному музеї «Тарасовій світлиці», яка знаходилася у хаті для доглядача могили Тараса Шевченка. До цих книг відвідувачі записували і записують свої думки і почуття. Любов’ю до Шевченка і болем за Україну наповнені записи шістдесятників: Михайлини Коцюбинської, Раїси та Валентини Морозів, Миколи Плахотнюка, Валентини Чорновіл, Олени Антонів, Івана Геля та багатьох інших. Однак зі спогадів старшого покоління музейних працівників відомо, що за цими книгами вражень пильно слідкувало КДБ, часто сторінки із «крамольними» записами виривалися.

Про діяльність шістдесятників написано чимало. Цілісну картину історичних процесів 1960-х - 1980-х років ще на початку 1990-х відобразив Георгій Касьянов ${ }^{3}$, який один із перших науково осмислив шістдесятництво на тлі історичної епохи як ланку безперервної боротьби українців за свою державність. Анатолію Русначенку належить грунтовна праця із дослідження спротиву українців, починаючи iз 1950-х років i до початку 1990-x . Широкою популяризацією діяльності шістдесятників стало створення Василем Овсієнком ${ }^{5}$, який сам $є$ їх представником, віртуального музею «Дисидентський рух в Україні», де зібрані біографічні дані про побратимів, їх спогади. Узагальнююче дослідження про діяльність Клубу творчої молоді у Києві «Сучасник» здійснив один із

3 Касьянов Георгій. Незгодні: українська інтелігенція в русі опору 19601980-х років. Київ : Либідь, 1995. 224 с.

${ }^{4}$ Русначенко А.М. Національно-визвольний рух в Україні середина 1950-х початок 1990-х років [Текст]. Київ : Вид-во ім. Олени Теліги, 1998. 720 с.

5 Овсієнко Василь. Віртуальний музей Дисидентський рух в Україні. URL: http://museum.khpg.org/index.php?id=1113923895. 
наймолодших шістдесятників - історик Сергій Білокінь ${ }^{6}$. Цінними, 3 погляду не лише фактологічного матеріалу, але й розуміння духу і настроїв молоді тих років, є видання мемуарного характеру: Ірини Жиленко ${ }^{7}$, Миколи Плахотнюка ${ }^{8}$, Михайлини Коцюбинської Світлани Кириченко ${ }^{10}$, Раїси Мороз ${ }^{11}$, Свгена Сверстюка ${ }^{12}$, Валерія Шевчука $^{13}$, Романа Корогородського ${ }^{14}$ та багатьох інших. Важливо, що окремі спогади підкріплюються щоденниковими записами, листами тих часів. Вони доповнюють один одного, створюють цілісну картину певних подій.

Окремо необхідно відзначити видання, присвячені одній особі, зокрема, Аллі Горській ${ }^{15}$; Івану Світличному ${ }^{16}$, Свгену Сверстюку ${ }^{17}$, Вячеславу Чорноволу ${ }^{18}$ Iз довідкових видань - енциклопедичний

${ }^{6}$ Білокінь С. Клуб творчої молоді «Сучасник» (1960-1965) в історії України другої половини XX століття /Персональний сайт : Режим доступу: https://www.sbilokin.name/history/SuchasnykIstUkr/Sources.

${ }^{7}$ Жиленко I. Homo Feriens: Спогади / Ірина Жиленко; передм. Михайлини Коцюбинської. Київ : Смолоскип, 2011. 816 с.

8 Плахотнюк Микола. Двадцять друге травня/Микола Плахотнюк. Коловорот: Статті, спогади, документи / Упорядкування та коментарі В. Чорновіл. Київ : Смолоскип, 2012. 510 с.

9 Коцюбинська М.Х. Книга споминів: пам'яті друга - Романа Корогородського - присвячую / Михайлина Коцюбинська. Вінниця: Акта, 2006. 283 с.

${ }^{10}$ Кириченко С. Люди не зі страху. Українська сага: Спогади/перед сл. Ю. Бадзьо / Світлана Кириченко. Київ : Смолоскип, 2013. 920 с.

${ }^{11}$ Мороз Р.В. Проти вітру. Спогади дружини політв'язня. Харків : Права людини, 2012. 288c.

${ }^{12}$ Сверстюк Є.О. На полі чести: у 2 кн. Кн. 1: Невже то я? / Упорядник Олексій Сінченко. Київ : Тов. «Видавництво «Кліо», 2015. $368+96$ с.іл.

${ }^{13}$ Шевчук В. На березі часу. Мій Київ. Входини: Автобіографічна оповідьесе. Київ : Темпора, 2002. 272 с.

14 Корогодський Р. Брама світла: Шістдесятники. Львів : Вид-во українського католицького університету, 2009. 656 с.

15 Червона тінь калини: Алла Горська: листи, спогади, статті / За ред. та упоряд. О. Зарецького, М. Маричевського. Київ : Спалах ЛТД, 1996. 240 с.

16 «Доброокий». Спогади про Івана Світличного /ред. рада: Вал. Шевчук та ін.; Упорядн. Леоніда і Надія Світличні. Київ : Вид-во «ЧАС», 1998. 572 с.

17 Сверстюк Є.О. На полі чести: у 2 кн. Кн. II. Наш сучасник Євген Сверстюк / Упорядник Василь Овсієнко. Київ : ТОВ Видавництво «Кліо», 2015. $600 \mathrm{c}$.

18 Деревінський Василь. В'ячеслав Чорновіл: журналіст, борець, державотворець : монографія. Тернопіль, 2013. 388 с. 
довідник Осипа Зінкевича ${ }^{19}$; збірник нарисів «Плеяда нескорених», виданий Національною парламентською бібліотекою (автор статей Л.Б. Тарнашинська ${ }^{20}$. Цій же авторці належить низка наукових праць, які стосуються шістдесятників, у літературознавчому аспекті ${ }^{21}$. Детальний аналіз русифікаторської політики радянської влади подано у відомій праці Івана Дзюби «Інтернаціоналізм чи русифікація», яку нині розглядаємо як історичне джерело ${ }^{22}$. Цінним зібранням документів, присвячених періоду 1960-1990-х рр., є десятитомне видання статей і матеріалів Вячеслава Чорновола, підготовлене до друку Валентиною Чорновіл (перші томи - спільно із Михайлиною Коцюбинською).

Це лише короткий огляд джерел, який засвідчує про значну джерельну та літературну базу для дослідження заявленої теми.

\section{2. Виступ проти русифікації України старшого покоління української інтелігенції у період підготовки до відзначення Шевченківських ювілеїв}

Культурницьку діяльність шістдесятників, їх творчі спроби підтримувало старше покоління, ті, кому вдалося вижити в період сталінізму. Зокрема, Валерій Шевчук їх називає «передшістдесятниками». Наводить приклад, як Павло Загребельний, на посаді редактора у 1961-63 pp. «Літературної газети» (згодом перейменованої у «Літературну Україну») надавав можливість друкуватися молодим авторам: Миколі Вінграновському, Івану Драчу,

${ }^{19}$ Рух опору в Україні 1960-1990. Енциклопедичний довідник / [гол. ред. О. Зінкевич]. Київ : Смолоскип, 2010. 804 с. 56 іл.

${ }^{20}$ Плеяда нескорених: Алла Горська. Опанас Заливаха. Віктор Зарецький. Галина Севрук. Людмила Семикіна: біобібліогр. нарис / авт. нарису Л.Б. Тарнашинська ; бібліограф-упоряд. М.А. Лук'яненко ; наук. ред. В.О. Кононенко ; М-во культури України, ДЗ «Нац. парлам. б-ка України». Київ, 2011. 200 с. (Шістдесятництво: профілі на тлі покоління; вип. 13.)

21 Тарнашинська Л. Українське шістдесятництво: профілі на тлі покоління (історико-літературний та поетикальний аспекти): монографія / Людмила Тарнашинська. Київ : Смолоскип, 2010. 632 с.

Тарнашинська Л. «Шевченко-поет сучасний»: прочитання крізь призму шістдесятництва / Людмила Тарнашинська. Київ : Вид-во Києво-Могилянська академія, 2017. $270 \mathrm{c.}$

22 Дзюба І. Інтернаціоналізм чи русифікація? / Іван Дзюба. Київ : Вид. дім «Києво-Могилянська акад.», 2005. 336 с. 
Володимиру Дрозду, Валерію Шевчуку; критикам Івану Дзюбі, Івану Світличному, Свгену Сверстюку та іншим ${ }^{23}$.

Добрим словом згадує старше покоління і Роман Корогородський, один із розділів його книги має назву: «Духові батьки шістдесятників» ${ }^{24}$. Насамперед мовиться про Бориса АнтоненкоДавидовича, Надію Суровцову, Григорія Кочура, Григорія Логвина і навіть тих, хто «часом згадували самих себе (Микола Бажан, Ірина Вільде, Максим Рильський).

За спогадами мисткині Галини Зубченко, членам Клубу творчої молоді для поїздок по Україні давав автобус авіазаводу Олег Костянтинович Антонов. Григорій Никонович Логвин очолював ці поїздки і знайомив молодь із історією культури українського народу. Михайло Брайчевський проводив екскурсії старим Київом. Мандруючи по Україні, звернули увагу, що втрачаються пам'ятки української культури. Вирішили звернутися до влади із листом, який написав Григорій Логвин, а літературно відредагувала Михайлина Коцюбинська. Лист було передано Максиму Рильському, завдяки подальшому клопотанню якого було засновано Товариство охорони пам'яток України ${ }^{25}$.

Найболючішим питанням було протистояння русифікації, яка у другій половині 1950-х рр. закріпилася законодавчо: 24 грудня 1958 p. Верховна Рада СРСР прийняла закон, відповідно до якого батькам і учням надавалося право самостійно вирішувати вивчати чи ні рідну мову в національних школах. При цьому вивчення російської мови було обов'язковим. Аналогічні постанови було прийнято на республіканському рівні.

Микола Плахотнюк описував гнітюче відчуття, яке викликав у нього зрусифікований Київ: «...ми всі відчули на собі жорсткі оберти жорен русифікаторської політики: у вищих і середніх спеціальних навчальних закладах викладання велося російською мовою, у державних установах повсюди нехтувалося вживання української мОВИ» ${ }^{26}$.

23 Шевчук В.О. На березі часу. Ті, котрі поруч: Спогади про сучасників. Київ : Либідь, 2015. С. 112.

${ }^{24}$ Корогородський Р. Брама світла. Батьки. Київ : Вид-во «Гелікон». 2004. C. $92-98$.

25 Зубченко Галина. А було це так. Алла Горська. Червона тінь калини: Листи, спогади, статті. Київ : Спалах, 1996. С. 153.

26 Плахотнюк Микола. Двадцять друге травня. Коловорот: Cmammi, спогади, документи / Упорядкування та коментарі В. Чорновіл. Київ : Смолоскип, 2012. С. 297. 
ХХ з’їд КПРС із розвінчанням культу особи Сталіна дав надію на демократизацію країни. Старше покоління української інтелігенції у період підготовки до відзначення ювілеїв Тараса Шевченка намагалося використати легальні методи, Шевченкове слово у протистоянні русифікації України. Яскравим прикладом такого спротиву є діяльність Тараса Івановича Франка.

У кінці 1950-х років, завдяки допомозі депутата Верховної Ради СРСР поета Павла Тичини, комуністи i комсомольці КорсуньШевченківська на Черкащині виступили із почином: «У кожну родину - «Кобзар», Шевченків портрет, репродукції його творів» ${ }^{27}$. Пропонувалось кожному учневі подарувати «Кобзар» 3 пам'ятним написом від школи, а також широко розповсюджувати поетичні Шевченкові твори, копії малярських робіт, відповідні сувеніри через книгарні та кооперативи ${ }^{28}$. Звернення черкащан оприлюднено у «Літературній газеті» (Київ, 28 квітня 1959 р.) $)^{29}$. Уже 2 березня 1961 p. «Литературная газета» (Москва) повідомляла про розповсюдження 25 тисяч «Кобзарів».

У НА ШНЗ зберігаються десятки копій листів, які Тарас Франко надсилав у різні урядові інстанції, наголошуючи на широкому відзначенні ювілеїв Тараса Шевченка, розповсюдженні його творів. Звертаючись до працівників музею Тараса Шевченка у Каневі, редакції місцевої газети «Дніпрова зірка», Тарас Іванович просив, щоб і вони його підтримали стосовно відзначення не лише ювілеїв Тараса Шевченка, але й пошанування пам'ятних дат Лесі Українки, Михайла Коцюбинського та інших світочів української культури. "А якщо затримаються із відповіддю Вам і доцільно нагадати - крапля ж довбе камінь» ${ }^{30}$. «Чи в кожній родині в Каневі буде портрет Т.Г. Шевченка, «Кобзар»? - запитував дирекцію заповідника на Тарасовій горі Тарас Франко ${ }^{31}$.

Тарас Франко надсилав запити до міністерств освіти радянських республік про кількість українців, які там мешкали, та чи є можливість дітям вивчати українську мову i, звичайно, отримував негативну відповідь ${ }^{32}$.

${ }^{27}$ НА ШНЗ, ф. 27, оп. 1, спр. 9, т. 2., арк. 15.

28 Лист Тараса Франка до Канівського музею-заповідника «могила Т.Г. Шевченка» від 30 травня 1960 р. / НА ШНЗ, ф. 27, оп. 1, спр. 8, арк. 28.

${ }^{29}$ НА ШНЗ, ф. 27, оп. 1, спр. 32, арк. 7.

30 Лист Тараса Франка до редакції газети «Дніпрова зірка» (м. Канів). НА ШНЗ, ф. 27, оп. 1, спр. 11, арк. 67.

${ }^{31}$ НА ШНЗ, ф. 27, оп. 1, спр. 9, т. 2., арк. 34 зв.

${ }^{32}$ НА ШНЗ, ф. 27, оп. 1, спр. 19, арк. 44. 
У зверненні від 26 жовтня 1960 р. до владних структур, яке підписали Тарас Франко, Назар Тобілевич, Платон Майборода та Василь Касіян, вказувалося на малу кількість видання книг українською мовою, тоді як в інших республіках ситуація краща. В листі наводилися дані із виступу на XX з'їзді КПРС першого секретаря ЦК компартії Естонії Івана Кебина, який повідомив, що за 10 років видано естонською мовою 40 млн книг для населення 1 млн 197 тис. $^{33}$.

У цей період йшло обговорення проекту програми КПРС. Тарас Франко у листі в редакцію газети «Правда» від 19 серпня 1961 р. пропонує до проекту програми КПРС внести пункт: «розвивати ленінське вчення про систематичну публікацію статистичних даних, зокрема в системі народної освіти (мова викладання в школах даної республіки, скільки літератури якими мовами надруковано) ${ }^{34}$.

Тема становища рідної мови в республіках продовжилася у листі групи української інтелігенції, яка, апелюючи до «ленінських норм» у національній політиці, у зверненні до редакції газети «Правда» від 28 серпня 1961 р., (підписаному дочкою Марка Кропивницького Ольгою, Дмитром Красицьким, Назаром Тобілевичем, Остапом Лисенком i Тарасом Франком), наводила статистичні дані про навчання рідною мовою в Україні. У листі зазначалося, що «порушники ленінських норм у період культу особи привели до того», що станом на 1958 р. у найбільших 9 містах України було 266 шкіл з українською мовою викладання, в яких навчалося 113899 учнів. Російських шкіл було вдвічі більше: 546 із 429186 учнями. Зокрема, у Київі - 51 українська школа (22 527 учнів), російських - 70 шкіл (61 217 учнів); Харків - 16 укр. шкіл (5 913 уч.), 76 рос. шкіл (63 836 уч.). Значної русифікації зазнавали міста і Західної України. Так, до прикладу, у Львові у 25 російських школах було 21750 учнів, більше, ніж українських (23 школи із 14790 учнями) $)^{35}$.

Автори підкреслювали, що понад 5 млн українців живе в інших республіках, найбільше - у Російській Федерації, але там немає жодної школи з українською мовою викладання. Пропонувалося за 2-3 роки в Україні зробити україномовними всі виші та середні спеціальні заклади, «по-ленінськи» перевести на українське діловодство усі раднаргоспи та заводоуправління. Для прикладу наводили Словаччину iз населенням 4 млн, де все викладається і ведеться словацькою мовою.

${ }^{33}$ НА ШНЗ, ф. 27, оп. 1, спр. 9, т. 1, арк. 22.

${ }^{34}$ НА ШНЗ, ф. 27, оп. 1, спр. 19, арк. 38.

${ }^{35}$ НА ШНЗ, ф. 27, оп. 1, спр .19, арк. 25. 
«Тоді і в батьків буде перспектива- вони будуть знати, що українська мова - не другосортна, не для домашнього вжитку». У згаданому листі пропонувалося до проекту Програми КПРС записати, що «процес добровільного вивчення, поруч із рідною мовою, російської мови, ні в якому разі не повинен розглядатися як процес витіснення рідної мови...» ${ }^{36}$.

25 жовтня 1961 р. Тарас Франко у листі до газети «Правда» подає «Пропозиції XXII з'їзду КПРС», в яких пропонує: «в Радянській конституції потрібно внести замість «права націй на самовизначення» положення: «Ніяких привілеїв у Радянському Союзі не може бути. Кожна республіка $\epsilon$ суверенною». Ця суверенність, на думку автора, повинна була забезпечуватися наступним: «Ніяка республіка не має права розпоряджатися територією іншої республіки і не може - без ясно висловленої вимоги з її сторони - посилати до неї своїх людей на роботу або для поселення. В школах даної республіки мовою викладання повинна бути мова о с н о в н о ї мови республіки (як в Словаччині - не чеська, а словацька) ${ }^{37}$.

Таким чином, Тарас Франко виступав проти підступних механізмів русифікації споконвічних українських земель, коли туди переселялися мешканці 3 Росії, а українців, навпаки, посилали на різні «комсомольські будови» або ж «піднімати цілину». Підкреслюючи виняткове право кожної республіки розпоряджатися своєю територією, він тим самим, фактично, пропонував надати самостійність республікам СРСР. Але «перемішування народів» тривало достатньо часу, тому Тарас Франко вказує, що батьки не повинні вирішувати, якою мовою навчатися дітям, адже школи ними не субсидуються, тобто не є приватними, а державні. Для прикладу: у школі не викладається закон Божий, хоча серед батьків $є$ і релігійні, які були б не проти.

Ми навели лише декілька фрагментів звернень Тараса Франка та його однодумців на захист рідної мови. НА ШНЗ зберігає багато інших копій подібних листів. Тарас Франко відзначав, що дороговказом у його житті були заповіти Тараса Шевченка: «Я вперше познайомився 3 могутньою творчістю безсмертного Кобзаря ще малим хлопцем, писав він, - «Заповіт» не тільки треба проспівати в свято і спочинок, але і в серці кожнім. Навчатися чужому, а свого цуратися, не в дусі Шевченка. Зробімо ж так, щоб анахронізмом пірнули в непам'ять

${ }^{36}$ НА ШНЗ, ф. 27, оп.1, спр. 19, арк. 25.

${ }^{37}$ НА ШНЗ, ф. 27, оп.1, спр. 19, арк. 47. 
побоювання великого співця, щоб сучасністю стали його ідеї, а дійсністю - його мрії» ${ }^{38}$.

\section{3. Офіційне відзначення ювілеїв Тараса Шевченка}

Широкому вшануванню ювілеїв Кобзаря сприяла низка об'єктивних і суб'єктивних факторів. Для керівництва радянської держави створилася вигідна ситуація поєднати святкування у контексті створення позитивного іміджу СРСР у сприйнятті країнами Західної Європи і США.

Із протоколів засідань республіканського та всесоюзного ювілейних комітетів видно вплив «хрущовської відлиги». Так, до прикладу, на засіданні Всесоюзного ювілейного комітету із відзначення 100-річчя від дня смерті Т. Г. Шевченка 31 січня 1961 р., де підводились підсумки зробленого, стосовно поновлення (встановленої ще у 1914 р.) меморіальної дошки у Ленінграді на будинку, де жив Тарас Шевченко, голова республіканського комітету Микола Бажан зазначив, що раніше створення таких дощок було «героїчним подвигом, оскільки було заборонено» (переклад 3 рос. Чорна Л.) ${ }^{39}$. А у виступі І.Г. Турбая визнавалося, що «період культу погано вплинув, ми видавали Шевченка, на жаль, з великими купюрами, крім академічного видання, котре незавершене, а видається воно з 1939 року» ${ }^{40}$.

Стенограми засідань Всесоюзного комітету свідчать про те, як Микола Бажан (голова Республіканського ювілейного комітету) послідовно відстоював проукраїнську позицію, пропонуючи передати в Україну всі мистецькі роботи Тараса Шевченка, які зберігалися у запасниках російських музеїв; відкрити у Москві бібліотеку із українськими книгами тощо.

28 червня 1961 р. могилу Тараса Шевченка вшанував керівник радянської держави Микити Хрущов: по дорозі до Відня, їдучи на зустріч із президентом США Джоном Кеннеді. У Каневі до його приїзду навіть побудували готель літнього типу «Тарасова гора».

${ }^{38}$ НА ШН3, ф.27, оп.1, спр. 23, арк. 3.

39 Стенограмма заседания Всесоюзного юбилейного комитета по проведению 100-летия со дня смерти Т.Г. Шевченко. 31 января 1961 года. Архів П.Т. Тронька. НА ШНЗ, ф. 2, оп. 1, спр. 1, арк. 27.

40 Стенограмма заседания Всесоюзного юбилейного комитета по проведению 150-летия со дня рождения Т.Г. Шевченко. 21 января 1963 года. Архів П.Т. Тронька, ф. 2, оп. 1, спр. 1, арк. 8. 
Загалом у 1961 р. Тарасову Гору відвідало 205 тисяч осіб; делегації із 26 країн світу ${ }^{41}$. У 1964 р. - 265 тис. осіб, в тому числі іноземці iз 47 країн ${ }^{42}$.

Необхідно відзначити, що українські дипломати на міжнародній арені доклали чимало зусиль у справі підготовки до 150-річчя від дня народження Тараса Шевченка. Документи із архіву П. Тронька «Заходи, здійснені Міністерством закордонних справ УРСР по відзначенню 150-річчя 3 дня народження Т.Г. Шевченка через ЮНЕСКО протягом 1960-1964 рр.» та «Шевченко і ЮНЕСКО» свідчать, що ще у листопаді 1960 р. українська делегація зробила заяву на XI сесії Генеральної конференції ЮНЕСКО із пропозицією відзначити 150-річчя українського поета. Спочатку отримали негативну відповідь із мотивацією, що на рівні ЮНЕСКО відзначають лише столітні дати, а інші не передбачені кошторисом. Проте ближче ознайомлення керівництва цієї міжнародної організації із феноменом Тараса Шевченка змінило ситуацію. Зокрема, у травні 1961 р. в СРСР побував генеральний секретар ЮНЕСКО Рене Майо. Під час свого візиту він відвідав Державний музей Тараса Шевченка в м. Київі. Особистість українського генія справила на нього велике враження. У травні 1962 р. на 61 сесії Виконавчої Ради ЮНЕСКО ім'я Тараса Шевченка було внесено до календаря ЮНЕСКО «Ювілеї великих людей і подій на 1964 рік» ${ }^{43}$. 15 червня 1962 р. на Тарасовій Горі побував А. Бертран, директор департаменту соціальних наук ЮНЕСКО. Оглянувши експозицію музею, записав у Книзі вражень: «Із хвилюванням я знайшов у Каневі, як і до того в Київі, в цьому прекрасному музеї, багаточисленні свідчення генію i героїзму Шевченка, символу мужності українського народу. Його приклад ніколи не вмре в серцях людей усього світу, в душі яких горить любов до волі» ${ }^{44}$.

На Заході духовна спадщина Тараса Шевченка сприймалася інакше, ніж в СРСР, де «офіційна наука» подавала його як «революціонерадемократа». Про різне трактування постаті Шевченка засвідчив і факт відмови у 1961 р. головним редактором «Кур'єру ЮНЕСКО» друкувати статтю відомого на той час радянського шевченкознавця Свгена Кирилюка про Тараса Шевченка, мотивуючи тим, що вона

\footnotetext{
${ }^{41}$ НА ШНЗ, Ф. 2, оп. 1, спр. 108, арк. 4.

${ }^{42}$ НА ШНЗ, Ф. 27, оп. 1, спр. 134, арк. 5.

${ }^{43}$ НА ШНЗ, ф. 35 , оп. 1. спр. 1, арк. 6.

${ }^{44}$ НА ШНЗ, ф. 34, оп. 1, спр. 31, арк. 138.
} 
«дуже академічна, суха і не розрахована на зарубіжного читача, який ще недостатньо знайомий із Шевченком» ${ }^{45}$. Статтю Свгена Кирилюка опублікували лише у російському виданні, а у французькому, іспанському, англійському та арабському - вийшла стаття англійської дослідниці Поліни Бентлі із назвою: «Тарас Шевченко - український співець свободи». Авторка трактувала Тараса Шевченка як «апостола свободи», відзначаючи, що «усе його життя відбивало страждання його рідної країни і незгасне бажання його народу стати вільним». Поліна Бентлі підкреслювала всесвітнє значення ідей Тараса Шевченка, насамперед - ідеї свободи ${ }^{46}$.

23 листопада 1962 р. під час XII Генеральної Конференції ЮНЕСКО у Парижі був проведений Шевченківський вечір, на якому прозвучала доповідь про життя i творчість Тараса Шевченка, демонструвалися фільми, а у вестибюлі розгорнули виставку, присвячену Шевченку, що було проти правил ЮНЕСКО, за якими виставки мали бути лише міжнародного значення, а не присвячені одній особі, проте Шевченку зробили виняток. На цій же конференції прийняли резолюцію про відзначення 150-річчя від дня народження Тараса Шевченка ${ }^{47}$.

Відповідно до ухвали ЮНЕСКО до ювілею Тараса Шевченка у «Колекції ЮНЕСКО видатних творів» вийшла повість «Художник» та уривки із «Щоденника». Транслювалися радіопередачі про Тараса Шевченка англійською, французькою та іспанською мовами. Також вийшли з друку вибрані твори у перекладі французького поета Ежена Гійєвика $з$ його передмовою та вступною статтею Максима Рильського та Олександра Дейча ${ }^{48}$. Ця невеличка книжечка нині є як у бібліотеці, так і у фондовій збірці Шевченківського національного заповідника. Цікаве іiї оформлення та структура: на першій сторінці обкладинки автопортрет молодого Тараса Шевченка (1845 р.): молоде, одухотворене обличчя, видно верхню частину модного одягу із краваткою. Окрім вступної статті, у виданні подано таблицю із трьох частин: факти із біографії Тараса Шевченка; паралельні події у царській Росії та у Свропі.

${ }^{45}$ ЦДАГО України.ф. 1, оп. 24, спр. 5894.

${ }^{46}$ ЦДАГО України.ф. 1, оп. 24, спр. 5894, арк. 10.

${ }^{47}$ НА ШНЗ.ф. 35.оп. 1. спр. 1, арк. 10-12.

48 Виступ на Міжнародному форумі діячів культури Павла Єршова заступника Генерального директора ЮНЕСКО / Радянська культура. № 4(979). 4 червня, 1964. С. 4. 
По лінії ЮНЕСКО були виділені кошти на проведення Міжнародного форуму діячів культури, який проходив у Київі і Каневі. 31 травня 1964 р. представники 43 країн вшанували могилу Кобзаря. Учасники форуму були під враженням феномену Тараса Шевченка, у своїх виступах порівнювали його із найгеніальнішими культурними діячами світу. Найкраще висловився Ежен Гійєвик (Франція) перекладач творів Тараса Шевченка: «Насамперед я пізнав у Тарасі чудову людину, - і тим-то не випадково, що він викликав у мене довір'я до себе, прихильність і симпатію. Це - добра, пряма, далекоглядна, рішуча людина. Це людина кришталевої чистоти... Він - голос народу. Він - втілення мрії людини про щастя. Це не диво. Це Шевченко $з$ усіма своїми індивідуальними особливостями» ${ }^{49}$.

\section{4. Вшанування Тараса Шевченка як вияв спротиву проти русифікації України}

У кінці 1950 - на початку 1960-х рр. нового змісту набула народна традиція - здійснювати щорічні поїздки на Тарасову гору. Однак, незважаючи на «хрущовську відлигу» та ювілеї поета, відвідувачі Тарасової гори, особливо із західних областей України, були під пильним наглядом «караючих органів».

Нині у залі пам'яті музею Тараса Шевченка експонується металевий вінок із дубового та лаврового листя, який поклала 1 травня 1961 р. на могилу Тараса Шевченка група молодих львів'ян (всього сто паломників, «бо така ювілейна дата»). Історія їх подорожі та подальші репресивні заходи влади (виклики до КДБ, звільнення з роботи) у спогадах Романа Головина (знаходяться у НА ШНЗ, надіслані автору статті у 1997 р. $)^{50}$.

На початку 1960-х років для студентів (Києва, Харкова, Одеси, Дніпропетровська, Львова та ін.) традицією стали поїздки на Тарасову гору. Збільшилося число екскурсантів у травневі дні. Валерій Шевчук пригадує поїздку до Канева під час відзначення 100 річчя перепоховання Тараса Шевченка у 1961 р.: «3 шостої години ранку почали іти до могили Шевченка люди. (...) перед нашими очима стелилася дорога, по якій повільно простували прості селяни, і чим далі, тим потік густішав, аж поки не став цілковитим (...) Прочувалося

49 Стенограма Міжнародного форуму діячів культури / Архів ШНЗ, ф. 35, оп1, спр. 2, арк. 125.

${ }^{50}$ Головин Роман(м. Львів). Тернистими стежками / НА ШНЗ, ф. 12, оп. 1 , спр. 1, арк. 2. 
тут щось глибше, може, до кінця й не усвідомлене, що й єднало їх у цей безкінечний потік» ${ }^{51}$.

На Тарасову гору їхала молодь не як до могили, а як до живого поета, щоб набратися сили духа, можливо, в думках поділитися тим, що не можна було висловити вголос. Побувало біля могили поета і молоде подружжя Морозів: Раїса і Валентин. 11 серпня 1961 р вони записали у Книзі вражень музею: «Спасибі, Батьку Тарасе, за те, що показав ти світові красу і силу нашого народу, що пробудив його в тяжку годину вогненним словом. Спи спокійно, Батьку. Ми пам'ятаємо твій заповіт. Раїса Мороз, Валентин Мороз, вчителі з Західної України» 52 . I подальшим своїм життям вони підтвердили свої слова. Світлана Кириченко також пригадувала, що перша спільна подорож іiі із чоловіком Юрієм Бадзьом після одруження була на Тарасову Гору ${ }^{53}$.

Відомо, що двічі могилу Шевченка вшанував мандрівний міжвузівський хор «Жайворонок» (м. Київ). Художниця Галина Зубченко описує перебування його у Каневі влітку 1962 р., виступи у Зеленому літньому театрі, участь в організації концерту Алли Горської i Василя Симоненка ${ }^{54}$. «Книга запису відвідувачів» за 1962 рік зафіксувала приїзд хору: 27 липня -22 особи ${ }^{55}$. Вдруге 43 хористи «Жайворонку» побували на Тарасовій горі 4 серпня 1963 p. ${ }^{56}$. Тут Василь Симоненко знову зустрічався із художницями Галиною Зубченко і Аллою Горською. Про спілкування із Аллою поет писав Івану Світличному 27 серпня 1963 р.: «Слава Україні! (...) ми зголосилися на тому, що слід ввести таке вітання: - Слава Україні! -

${ }^{51}$ Шевчук В. На березі часу. Мій Київ. Входини: Автобіографічна оповідьесе. Київ : Темпора, 2002. С. 160.

52 Книга вражень Канівського музею-заповідника «Могила Т.Г. Шевченка»: 1960-1961рp. / Фонди ШНЗ. КН.-21829, А. 207. Арк. 35.

${ }^{53}$ Кириченко С. Люди не зі страху. Українська сага: Спогади / перед сл. Ю. Бадзьо. Київ : Смолоскип, 2013.

54 Зубченко Галина. А було це так. Алла Горська. Червона тінь калини: Листи, спогади, статті. Київ : Спалах, 1996. С. 151-153.

55 Книга реєстрації відвідувачів Канівського державного музею-заповідника «Могила Т. Г. Шевченка»: розпочато 02.IX.1961 - зак. 26.XII.1962. - на 115 арк. / Науковий архів ШН3, ф. 6, оп. 1, спр. 22, арк. 62.

${ }^{56}$ Книга реєстрації відвідувачів Канівського державного музею-заповідника «Могила Т.Г. Шевченка»: розпочато: 01.01.1963 - зак. 21.XI.1963 / Науковий архів ШНЗ, ф. 6, оп. 1, спр. 23., на 120 арк. Арк. 84. 
Навіки слава! Агітую тебе приставати до нашого тріумвірату...» ${ }^{57}$. На жаль, невдовзі поет став першою жертвою із когорти шістдесятників.

У фондах Шевченківського національного заповідника знаходиться малюнок-афіша «Жайворонок», виконаний у 1963 р. Аллою Горською (подарований ШНЗ у 2000 р. Зарецьким Олесем Вікторовичем).

Духовна спадщина Тараса Шевченка значною мірою вплинула на формування поглядів шістдесятників. Яскравим прикладом цього $\epsilon$ навернення до української мови російськомовної Алли Горської, яка пізніше стала одним із символів цього покоління. Художниця Галина Зубченко пригадувала, з яким запалом Алла брала участь у оформленні Шевченківських вечорів у художній школі ${ }^{58}$. Пізніше шевченківська тема по-новому зазвучала у їі творчості.

У Києві центром протистояння між українськими патріотами і комуністичною владою став пам'ятник Тарасу Шевченку навпроти університету його імені. У березні 1960 р. студенти Київського держуніверситету ім. Т.Г. Шевченка вперше самоорганізувалися, щоб покласти квіти до пам'ятника Кобзарю59. А наступного, 1961 р., молодь згуртовано прийшла до Шевченка уже у знаковий день для українців (перепоховання в українську землю) - 22 травня $^{60}$. Це був початок довгого протиборства українців і комуністичної влади за право без цензури i окремих дозволів вшановувати не лише Тараса Шевченка, але й інших видатних українців. Кияни щорічно почали приходити до пам'ятника Тарасу Шевченку, читати його твори, співати, влаштовувати літературні вечори. «Хрущовська відлига» тривала недовго. Насамперед про це засвідчило нищення напередодні 9 березня 1964 р. (150-річчя від дня народження Тараса Шевченка) вітражу «Шевченко. Мати» у Київському державному університеті ім. Т.Г. Шевченка. Задум мозаїки належав Аллі Горській та Людмилі Семикіній, до роботи долучилися Опанас Заливаха, Галина Зубченко, Галина Севрук та Віктор Зарецький.

57 Симоненко Василь. Листи до Івана Світличного. URL: https://vasylsymonenko.in.ua/lysty/ivana-svitlychnogo-4/\#.WalIxPfJzIU - Заголовок з екрану.

58 Зубченко Галина. А було це так. Алла Горська. Червона тінь калини: Листи, спогади, статті. Київ : Спалах, 1996. С. 148.

${ }^{59}$ Шевчук В. На березі часу. Мій Київ. Входини: Автобіографічна оповідьесе. Київ : Темпора, 2002. С. 136.

60 Чорновіл В. Про відзначення в Києві роковини перевезення тіла Тараса Шевченка на батьківщину. Твори: у 10-ти томах. т.3 / Упор. В. Чорновіл. Передм. М. Косів. Київ : Смолоскип, 2006. С. 608. 
Напередодні 22 травня 1964 р. влада почала застосовувати превентивні репресивні заходи. Як свідчать архівні документи (доповідна записка секретарю ЦК КПУ М.О. Соболю від секретаря ЦК ЛКСМУ Ю. Сльченка), був затриманий активний організатор зібрання біля пам'ятника Тарасу Шевченку студент-медик Микола Плахотнюк, який із Свгеном Сверстюком закликав студентів прийти до пам'ятника поету. Цією справою зацікавилися партійні, комсомольські органи та КДБ ${ }^{61}$. Було зафіксовано імена тих, хто 22 травня 1964 р. у Києві прийшов до пам'ятника Тарасу Шевченку: Б. Антоненко-Давидович, М. Коцюбинська, Є. Сверстюк, І. Світличний, Т. Цимбал, І. Жиленко, А. Горська, Л. Семикіна, Г. Зубченко, М. Стороженко, О. Бердник, Г. Тютюнник, Л. Ященко, О. Пономаренко, О. Бадзьо, П. Бойко, М. Холодний та багато інших, - всього біля 70 осіб ${ }^{62}$.

Один із аргументів заборони вільного вшанування Тараса Шевченка висловив перший секретар Київського обкому комсомолу: «Збиратися до пам’ятника Шевченкові 22 травня - це образа великому російському народові» ${ }^{63}$.

Під час відзначення ювілеїв Тараса Шевченка повсюди відбувалися Шевченківські вечори. Раїса Мороз пригадувала, з яким натхненням їх проводили львів'яни: «... Усюди концерти, читання лекцій, конференції. Концерти щовечора, і щовечора ущерть виповнені зали філармоній; квитка купити неможливо. I кожний такий концерт перетворювався на тріюмф Шевченкового слова й генія» ${ }^{64}$. Раїса Мороз зазначала, що дуже швидко влада зрозуміла небезпеку таких вечорів: в хід пішли потаємні інструкції і почали зникати вечори й концерти, присвячені поетові. Березень перестав бути Шевченковим. Раптом неабиякого значення набуло свято Жінки 8 березня. Про заборону вшановувати Тараса Шевченка 22 травня пізніше, в еміграції, Раїса Мороз писала: «Любов до Шевченка, однак, не так легко вбити. Навіть пропущений через густе сито цензури, підстрижений і приглажений казенною радянською щіткою, цілком хрестоматійний він промовляє до людських сердець, будить їхнє сумління» ${ }^{65}$.

${ }^{61}$ ЦДАГО України, ф. 1, оп. 24, спр. 5894, арк. 163-165.

62 ЦДАГО України, ф. 1, оп. 24, спр. 5894, арк. 164.

63 Чорновіл В. Про відзначення в Києві роковини перевезення тіла Тараса Шевченка на батьківщину. Вячеслав Чорновіл. Твори: у 10-ти томах. т. 3 / Упор. В. Чорновіл. Передм. М. Косів. Київ : Смолоскип, 2006. 976 с. С. 608.

${ }^{64}$ Мороз Раїса. Шевченко в сучасній Україні. Український голос, 4 травня 1987 р. Вінніпег : В-во «Канадійський фермер».

${ }^{65}$ Мороз Раїса. Шевченко в сучасній Україні... 
У кінці серпня - на початку вересня 1965 р. в українських містах (Києві, Львові, Івано-Франківську, Одесі, Тернополі, Луцьку) пройшли масові арешти - «перший покіс» української свідомої інтелігенції. Так завершився мирний, «культурницький» період діяльності шістдесятників.

Уже перші арешти стали тим вододілом, який розмежував справжніх патріотів України від тих, хто скорився владі. Серед нескорених був i Микола Плахотнюк, життєву позицію якого зафіксував запис від 8 травня 1968 р. у Книзі вражень музею Тараса Шевченка: «<..> на Україні, за яку так багато вистраждав поетдемократ, майже ніде не знайдеш вузу, де б нащадки Тарасові могли слухати лекції його мовою. А попробуйте відшукати в Києві професійно-технічне училище, чи інші освітні курси 3 викладовою мовою народу, який дав світові такого велета Духа? То чому так сталося ??! < ..> Так, це повинно хвилювати кожну людину, бо мова народу - то його душа. А без душі немає жодного народу. $<\ldots>»{ }^{66}$.

Вдруге у 1968 р. на Тарасовій горі Плахотнюк побував 17 серпня разом із Ніною Строкатою-Караванською, супроводжувати яку попросив Миколу Василь Стус, оскільки йому на той час заборонено було покидати Київ ${ }^{67}$.

«І знову я прийшов вклонитися українській святині - могилі Тараса Шевченка. Гарно, що нестримним потоком ідуть та ідуть сюди люди. Гарно, що у цій книжці люди висловлюють свою любов до багатостраждального, геніального сина України, до людини, яка понад усе любила свій народ, свою Батьківщину. А чи всі глядачі шанують мову народу, з якої вийшов Тарас? Чи всім відомо, що в університеті ім. Шевченка в Києві студенти не мають можливості вчитись рідною мовою? А що ми для цього зробили, аби здійснити Заповіти Шевченка? Отже, мабуть, потрібно уявити собі, якою хотів бачити Україну Шевченко, щоб записати, що його заповіти виконані. Виявляється, не досить мати сало, хліб і до хліба, щоб говорити про виконання заповітів. То що ж тоді треба? Треба читати уважніше Шевченка. Хоча б такі слова:

Учітеся, брати мої,

66 Книга вражень 1967-1968p. Канівський державний музей-заповідник «Могила Т.Г. Шевченка» Черкаської обл.: 8 липня 1967 - 15 червня 1968 р. C. 490.

67 Плахотнюк Микола. Коловорот: Статті, спогади, документи / Упорядкування та коментарі В. Чорновіл. Київ : Смолоскип, 2012. С. 218. 
Думайте, читайте.

I чужому научайтесь,

Свого не цурайтесь.

Димер на Київщині.

Лікар Плахотнюк» ${ }^{68}$.

Відомий науковець, шістдесятник Свген Сверстюк, пригадуючи початок 1960-х років, відзначав, що у той час надходило чимало листів до Спілки письменників України, де «нарікали на русифікацію» ${ }^{69}$. Часто автори брали аргументи із праць Леніна, в яких висвітлювалася національна проблема, цим самим убезпечуючи себе. Саме таким чином, із початковим задумом як лист до вищих державних та партійних органів, виникла аналітична праця Івана Дзюби «Інтернаціоналізм чи русифікація» (1965р.), в якій, за допомогою конкретних цифр i фактів, автор обгрунтовував катастрофічне становище української мови в республіці. За визначенням науковця, український народ перебував «під мовною блокадою» ${ }^{70}$. Особливо активно йшла русифікація міст: «...українець (який усвідомлює себе українцем) почуває себе в місті в Україні, як на чужині, «на нашій, не своїй землі» (слова Шевченка)», - писав І. Дзюба ${ }^{71}$.

\section{ВИСНОВКИ}

Розглядаючи події в Україні початку 1960-х років, необхідно відзначити, що ювілеї Тараса Шевченка були своєрідним каталізатором демократичних процесів у житті республіки у період «хрущовської відлиги». Старше покоління української інтелігенції намагалося використати легальні можливості для зупинення русифікації України, виступаючи із відповідними зверненнями до вищих органів радянської влади.

Молодь (особливо творча) створювала об'єднання: у Києві - Клуб творчої молоді, Львові - аналогічний клуб «Пролісок». Розвивалися

68 4.Книга вражень 1968 - 1969p. Канівський державний музей-заповідник «Могила Т.Г. Шевченка» Черкаської обл.: 15 червня 1968-12 травня 1969 р. C. 282.

${ }^{69}$ Сверстюк С.О. На полі чести: у 2 кн. Кн. 1: Невже то я? / Упорядник Олексій Сінченко. Київ : Тов. «Видавництво «Кліо», 2015. С. 141.

${ }^{70}$ Дзюба I. Інтернаціоналізм чи русифікація? Київ : Вид. дім «КиєвоМогилянська акад.», 2005. С. 168.

71 Дзюба І. Інтернаціоналізм чи русифікація? Київ : Вид. дім «КиєвоМогилянська акад.», 2005. С. 207. 
нові напрями у театрі, малярстві, поезії; відроджувалися народні звичаї і традиції (колядки, щедрівки); зазвучали народні пісні.

По суті, ішла боротьба за Шевченка: українська інтелігенція добивалася права не лише вільно вшановувати свого національного поета, але й виконувати його заповіти - берегти і розвивати українську мову.

Тарас Шевченко, його духовна спадщина по-різному сприймалися зарубіжною громадськістю, українськими патріотами та комуністичною владою.

На початку 1960-х років відбувалося масове паломництво до могили національного поета на Тарасову Гору. Книги вражень музею Тараса Шевченка фіксують прагнення українців зберегти рідну мову, національну культуру. У Києві для молоді стало традицією збиратися біля пам'ятника Тарасу Шевченку у дні його народження, смерті та перепоховання. 3 часом влада почала забороняти «самовільне» вшанування Кобзаря, застосовуючи репресивні методи. Під особливу заборону попав день 22 травня - перепоховання Тараса Шевченка в Україні, який пов'язували із націоналістичними поглядами шанувальників.

Культурницька діяльність шістдесятників, яка згодом переросла у політичний опір радянській системі, стала ще однією ланкою у боротьбі українців за свою державність. Саме тому початок 1960-х років образно називають «битвою за Шевченка».

\section{АНОТАЦЯ}

Творчість Тараса Шевченка, його заповіти, висловлені у поетичній формі, і нині є актуальними, сприяють самоідентифікації українців, формуванню національної ідеї. Заклики видатного мислителя: «борітеся - поборете!»; будувати «свою хату»-державу, не зрікатися рідної мови - і в XXI столітті все ще на часі. В кінці 1950-х - на початку 1960-х років із іменем Тараса Шевченка пов'язувалися надії на демократизацію суспільства, призупинення русифікації України, відродження української мови і національної культури.

У дослідженні акцентується на значенні творчості Тараса Шевченка для покоління української інтелігенції, яке увійшло в історію як шістдесятники. Обгрунтовано вплив відзначення ювілеїв Тараса Шевченка 1961-1964 років на самоусвідомлення українців, участь старшого покоління в організації відзначення пам'ятних дат, поширенні Шевченкового слова. 
Підкреслюється бажання радянської влади контролювати вшанування Тараса Шевченка, її страх перед самоорганізованістю українців.

Прослідковано, як поступово відзначення 22 травня - дня перепоховання Тараса Шевченка - попало під заборону радянської влади, стало символом боротьби українців проти тоталітаризму, а культурницька діяльність шістдесятників перейшла у політичну площину.

\section{ЛІТЕРАТУРА}

1. Білокінь С. Клуб творчої молоді «Сучасник» (1960-1965) в історії України другої половини XX століття / Персональний сайт. URL: https://www.sbilokin.name/history/SuchasnykIstUkr/Sources.

2. Головин Роман. Тернистими стежками / Науковий архів ШНЗ, ф.12, оп.1, спр.1.

3. Дзюба I. Інтернаціоналізм чи русифікація? Київ : Вид. дім «Києво-Могилянська акад.», 2005. 336 с.

4. «Доброокий». Спогади про Івана Світличного / ред. Рада : Вал. Шевчук та ін. ; Упорядн. Леоніда і Надія Світличні. Київ : Вид-во «ЧАС», 1998. $572 \mathrm{c}$.

5. Жиленко I. Homo Feriens: Спогади ; передм. Михайлини Коцюбинської. Київ : Смолоскип, 2011. 816 с.

6. Зубченко Галина. А було це так. Алла Горська. Червона тінь калини: Листи, спогади, статті. Київ : Спалах, 1996. С. 148-157.

7. Касьянов Г. Незгодні: українська інтелігенція в русі опору 1960-х - 80-х років. Київ : Либідь, 1995. 224 с.

8. Кириченко С. Люди не зі страху. Українська сага: Спогади / перед сл. Ю Бадзьо. Київ : Смолоскип, 2013. 920 с.

9. Книга вражінь. 1949. 22 травня 1949 - 25 грудня 1949. 172 с. / Фонди ШНЗ, кн-21817.

10. Книга реєстрації відвідувачів Канівського державного музеюзаповідника «Могила Т.Г. Шевченка»: розпочато 02.IX.1961 - зак. 26.XII.1962. - на 115 арк. / НА ШНЗ, ф. 6, оп. 1, спр. 22.

11. Книга реєстрації відвідувачів Канівського державного музеюзаповідника «Могила Т.Г. Шевченка»: розпочато: 01.01 .1963 - зак. 21.XI.1963 / НА ШНЗ, ф. 6, оп. 1, спр. 23., на 120 арк.

12. Корогородський Р. Брама світла. Батьки. Київ : Вид-во «Гелікон». 2004. 472 с. 
13. Корогодський Р. Брама світла: Шістдесятники / Роман Корогодський. Львів : вид-во українського католицького університету, $2009.656 \mathrm{c}$.

14. Коцюбинська М.Х. Книга споминів: пам'яті друга - Романа Корогородського - присвячую. Вінниця : Акта, 2006. 283 с.

15. Мороз Р.В. Проти вітру. Спогади дружини політв'язня. Харків : Права людини, 2012. 288 с.

16. Овсієнко Василь. Віртуальний музей Дисидентський рух в Україні. URL: http://museum.khpg.org/ index.php?id=1113923895.

17. Плахотнюк Микола. Двадцять друге травня. Коловорот: Cтатті, спогади, документи / Упорядкування та коментарі В. Чорновіл. Київ : Смолоскип, 2012. 510 с.

18. Плеяда нескорених: Алла Горська. Опанас Заливаха. Віктор Зарецький. Галина Севрук. Людмила Семикіна: біобібліогр. нарис / авт. нарису Л.Б. Тарнашинська ; бібліограф-упоряд. М.А. Лук'яненко ; наук. ред. В.О. Кононенко ; М-во культури України, ДЗ «Нац. парлам. б-ка України». Київ, 2011. 200 с. (Шістдесятництво: профілі на тлі покоління; вип. 13).

19. Русначенко А.M. Національно-визвольний рух в Україні середина 1950-х - початок 1990-х років [Текст]. Київ : Вид-во ім. Олени Теліги, 1998. 720 c.

20. Сверстюк С.О. На полі чести: у 2 кн. Кн. 1 : Невже то я? / Упорядник Олексій Сінченко. Київ : Тов. «Видавництво «Кліо», 2015. $368+96$ с. іл.

21. Сверстюк Є.О. На полі чести : у 2 кн. Кн. II. Наш сучасник Євген Сверстюк / Упорядник Василь Овсієнко. Київ : ТОВ Видавництво «Кліо», 2015. 600 c.

22. Симоненко В. Листи до Івана Світличного. URL: /https://vasylsymonenko.in.ua/lysty/ivana-svitlychnogo-4/\#.WalIxPfJzIU заголовок з екрану.

23. Тарнашинська Л. Українське шістдесятництво: профілі на тлі покоління (історико-літературний та поетикальний аспекти) : монографія. Київ : Смолоскип, 2010. 632 с.

24. Тарнашинська Л. «Шевченко-поет сучасний»: прочитання крізь призму шістдесятництва. Київ : Вид-во Києво-Могилянська академія, 2017. $270 \mathrm{c}$.

25. Франко І. Присвята. Твори в 50-ти томах. Київ : Наукова думка, 1983. T. 39. 703 c.

26. Чорновіл В. Про відзначення в Києві роковини перевезення тіла Tараса Шевченка на батьківщину. В'ячеслав Чорновіл. Твори: 
у 10-ти томах. т. 3 / Упор. В. Чорновіл. Передм. М. Косів. Київ : Смолоскип, 2006. $976 \mathrm{c.}$

27. Шевченко Т.Г. І мертвим, і живим і ненарожденним в Україні і не в Україні моє дружнєє посланіє. Зібрання творів : У 6 т. Київ, 2003. Т. 1: Поезія 1837-1847. С. 348-354.

28. Шевчук В. На березі часу. Мій Київ. Входини: Автобіографічна оповідь-есе / Валерій Шевчук. Київ : Темпора, 2002. 272с.

29. Шевчук В.О. На березі часу. Ті, котрі поруч: Спогади про сучасників. Київ : Либідь, 2015. 576 с.

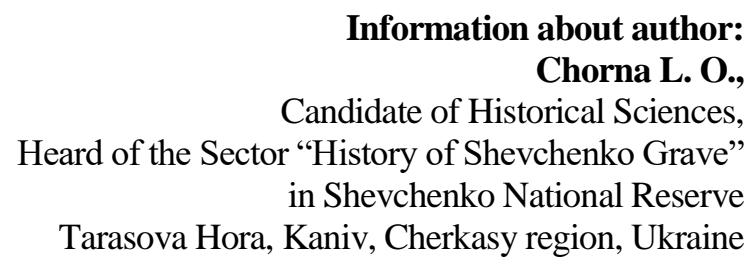

